\section{Tisztelt Szerkesztôség!}

Az Orvosi Hetilap 2016. évi 51. számának Esetismertetés rovatában (Orv. Hetil., 2016, 157(51), 2048-2050.) megjelent az „Egészséges gyermek születése karyomapping eljárással történó preimplantációs genetikai diagnózist követôen” (Nánássy László dr., Téglás Gyöngyvér, Csenki Marianna dr., Vereczkey Attila dr.) címú közlemény.

Az esetismertetés 2049. oldalának közepén szerepel, hogy „Az embriót ezt követöen vitrifikáció útján fagyasztottuk a későbbi esetleges felhasználásig. A bioptátumot PCR-csöbe helyeztük kétszeri PBS- és 1\% PVP-oldatban történó átmosást követöen, és -20 $C^{\circ}$-on tároltuk a genetikai diagnosztikai laboratóriumba való szállitás elött. ... A karyomapping eljárás során az embriót heterozigóta hordozóként diagnosztizáltuk.”

A Versys Clinics Humán Reprodukciós Intézet - ahol az eset történt - nem rendelkezik genetikai diagnosztikai laboratóriummal. A Reprogenex Géndiagnosztikai Laboratórium, illetve biobank múködési engedélyét - amely korábban a Versys laborjaként volt ismert - 2014-ben az OTH visszavonta. A leírt eset a cikk szerint 2015 ben történt.

A szerzők a hatósági tiltás után nyilván más genetikai diagnosztikai laborba szállították a vizsgálandó bioptátumokat, mert a közlemény szerint: „2015. január óta intézetünkben négy alkalommal végeztünk IVFhez kapcsolódó PGD-eljárást különbözőöörökletes megbetegedések vizsgálatára." A közlemény olvasásakor felmerül a kérdés még a szúk szakmát jól ismerő orvosok és biológusok körében is, hogy a szerzők vajon miért titkolták el közleményükben a karyomappinget végző genetikai diagnosztikai laboratórium nevét.

Tudomásunk szerint az Orvosi Hetilapban leírt eset során a bioptátumot egy külföldi genetikai diagnosztikai laboratóriumba szállitották $k i$ a vizsgálat elvégzése érdekében.

Időközben ebben az ügyben kikértük az ÁNTSz állásfoglalását is. Válaszukat idézve: „.... törvény nem tiltja, illetve bejelentéshez sem köti a genetikai minták Európai
Unión belüli diagnosztikus célú továbbítását." Miután az esetismertetés érdemi része a genetikai laboratóriumban történt, a szerzőktól elvárható lett volna, hogy a külföldi genetikai labor neve is említésre kerüljön.

Tisztelettel: Török Attila dr.

\section{Tisztelt Szerkesztöség!}

Örömmel olvastuk, hogy preimplantációs genetikai vizsgálatokat nem végző intézet vezetője is érdeklődik a modern asszisztált reprodukció ezen vívmánya iránt. Szívesen megválaszoljuk a cikkel kapcsolatos egyetlen kérdésüket, amely arra irányul, melyik molekuláris diagnosztikai laboratórium végezte a minta értékelését.

A molekuláris biológiai vizsgálat nem az intézet keretein belül, hanem külföldön történt. Mivel az eredmény hivatalossá válásához a genetikai tanácsadás során klinikai genetikus szakvéleménye szükséges, ezért véleményünk szerint a „diagnosztizáltuk" kifejezés nem túlzó.

Nem teljesen értjük, miért fontos a vizsgálatot végző labor neve. Szakmai szempontból semmilyen relevanciával nem bír, hogy melyik labor és hol végezte a vizsgálatot. Az intézetünkben lefolytatott hatósági ellenőrzések során a genetikai diagnosztikai szolgáltató laboratórium és az intézetünk közötti szerződések szemrevételezésre kerültek, azokkal kapcsolatban semmilyen kifogást nem kaptunk.

Mint arra a levélíró is utal, az ÁNTSZ nem tiltja külföldi laboratóriumok segítségének igénybevételét.

Az esetbemutatás célja az volt, hogy közöljük, intézetünkben elérhető a jelenleg legmodernebb preimplantácios genetikai diagnosztikai módszer, és beszámoljunk annak első sikeres magyarországi alkalmazásáról. A cikk az eljárás klinikai jelentőségét írja le, a molekuláris genetikai technológia leírása elnagyolt, ami egy esetleírásnál teljesen elfogadható.

Meg kell, hogy védjük az Orvosi Hetilap szerkesztőségét is, mivel levelük konkrétan felrója részükre, hogy tájékozatlanok voltak intézetünkkel kapcsolatban. A cikkeket közlő szaklapok sem múködési engedélyeket, sem megfelelőségi tanúsítványokat, egyáltalán semmilyen jogi engedélyt, személyi feltételt nem kell, hogy vizsgáljanak, ezért megjegyzést tenni erre érthetetlen.

A félreértések elkerülése végett közöljük, hogy intézetünket soha nem tiltották el a preimplantciós genetikai diagnosztikai (PGD) vizsgálatok végzésétôl. A levél írója valószínúleg a preimplantációs genetikai szürésre (PGS) gondolt, amelynek használata szakmai vita a hatóság és intézetünk között. A reprodukciós genetikában kevésbé jártas szakemberek könnyen összekeverhetik a két eljárást, habár mind a vizsgálat céljában, mind az alkalmazott molekuláris genetikai módszerekben élesen elkülönül a kettő. A Humán Reprodukciós Bizottság több állásfoglalása is helyesen leírja a két eljárás közötti különbséget (ett.aeek.hu). A preimplantációs genetikai diagnosztikai vizsgálat engedélyezett eljárás Magyarországon, a preimplantációs genetikai szürés hazai alkalmazásának tiltásának jogosságát pedig jelenleg közigazgatási eljárásban vizsgálják.

Eddig minden, az intézetünk által Magyarországon bevezetett új, a kezelések eredményességét javító módszerrel kapcsolatban kaptunk észrevételt a Magyar In Vitro Fertilizációs Társaságtól, amire minden esetben reagáltunk is. Mi örvendünk annak, hogy e társaság nem rest aggodalmát kifejezni nyilvánosan, és elkötelezett a magyarországi páciensek minél magasabb szintű kezelésében, ezért javasoljuk, hogy a nyugati országokban már sikeresen alkalmazott módszereket támogassa, azok mielőbbi hazai bevezetését szorgalmazza. Mi szeretnénk biztosítani Önt és társaságát, hogy intézetünk ehhez minden tôle telhető szakmai támogatást meg fog adni, segít megfogalmazni szakmai protokollokat, állásfoglalásokat, megrendezni szakmai találkozókat, amelyek elősegíthetik a fent említett cél elérését.

Tisztelettel: Nánássy László $d r$. 


\section{Csecsemö- és gyermekgyógyászat}

Terhesség alatt pertussis ellen oltott anyák koraszülöttjeinek pertussisellenes antitesttiterkoncentrációja (Pertussis antibody concentrations in infants born prematurely to mothers vaccinated in pregnancy) Kent, A., Ladhani, S. N., Nick, J., et al., on behalf of the PUNS Study Group

(Paediatric Infectious Diseases Research Group and Vaccine Institute, St. George's, University of London, London, Egyesült Királyság; e-mail: alisonkent@doctors.org.uk):

Pediatrics, 2016, 138(1), e20153854

doi: 10.1542/peds.2015-3854

A terhes nők részére a harmadik trimeszterben adott pertussis elleni védőoltás hatékony, és az újszülöttekre nézve kifejezetten védőhatású. Eddig tisztázatlan és bizonytalan volt annak megítélése, hogy ugyanez a megállapítás érvényes-e koraszülöttekre is.

Egy Egyesült Királyságban végzett tanulmány szülést követően vizsgálta a koraszülöttek antitesttiter-értékét. A vizsgálatba 160 terhes anyát vontak be. 31 anya esetében, akik koraszülött gyermeknek adtak életet, a terhesség 28. hetében egy kombinált diphteria-tetanus-pertussis-polio oltást adtak be. A kontrollcsoporto 129 nem oltott anya-koraszülött gyermek pár képezte. Az antitesttiter-értékeket a koraszülöttek két hónapos korában - még az első kötelező védőoltás beadása előtt -, továbbá az ötödik és a 12 . hónapban vizsgálták. Az „oltottak” esetében a második hónapban az antitesttiter magasabb volt, ugyanakkor az ötödik hónapban (az elsố „saját védőoltás” után) az antitesttiter már alacsonyabb értéket adott, mint a kontrollcsoportban. 12 hónapos korban a két vizsgált csoport között már nem volt különbség. Ezért a szerzők javasolják, hogy a terhes anyák részére a pertussis elleni védőoltás a harmadik trimeszter elején, lehetőleg minél korábbi időpontban kerüljön beadásra

Schmidt Péter dr.

\section{Diabetológia}

A 2-es típusú diabetes (2DB)

és a cardiovascularis (CV)

betegségek incidenciája 1,9 millió

beteg kohorszvizsgálata alapján

(Type 2 diabetes and incidence of

cardiovascular diseases: a cohort study in 1.9 million people) Shah, A. D., Langenberg, C., Rapsomaniki, E., et al. (Farr Institute of Health Informatics Research at London, University College London, London NW1 2DA, Egyesült Királyság; e-mail: anoop@doctors.org.uk)

Lancet Diabetes Endocrinol., 2015, $3(2), 105-113$

A tanulmány a $2 \mathrm{DB}$ és a korai CV-esemény egyidejú előfordulása közötti kapcsolatot vizsgálta. Követéses kohorszvizsgálatról volt szó. Elsődleges végpontnak tekintették egy adott betegnél a következő CV-esemény bármelyikéről készült, az adatbázisokból származó legelső feljegyzést: stabil angina pectoris, instabil angina, myocardialis infarctus, előre nem jelezhető coronariaeredetű halálozás, szívelégtelenség, átmeneti ischaemiás attak, ischaemiás stroke, subarachnoidealis vérzés, intracerebralis vérzés, perifériás artériás betegség, hasi aneurysma, valamint vagy arrhythmiaként, vagy hirtelen szívhalálként osztályozott összetett végpont, amelynek komponensei a cardioversio, a bal kamrai arrhythmia, az implantálható cardioverterdefibrillátor, a szívmegállás vagy a hirtelen szívhalál voltak. Az elemzések során csak az első feljegyzéseket vették figyelembe.

Másodlagos végpontként definiálták a CV- és a bármely okból bekövetkező halálozást.

Jelen vizsgálat arra a - korábbi kohorszvizsgálatokból és metaanalízisekből már ismert - megállapításokra épült, amely szerint diabetesben számos atheroscleroticus CV-betegség kialakulásának magasabb a kockázata. A szerzók igazolták, hogy ez az összefüggés különösen helytálló a 2-es típusú diabetes esetében. Ebben a kórképben a CV-betegségek leggyakoribb korai manifesztációja a perifériás artériabetegség és a szívelégtelenség. A vizsgálati eredmények alátámasztják azon korábbi, kisebb méretű tanulmányok megállapításait, amelyek szerint diabetesben alacsonyabb a hasi aneurysma és egy lehetséges subarachnoidealis vérzés kockázata. Ezeknek a megállapításoknak fontos jelentősége lehet a be tegségmodellezés és a klinikai kockázatfelmérés szempontjából.

Fischer Tamás dr.

\section{Pulmonológia}

Farmon felnövekedés hatása
a felnőttkori tüdőfunkcióra
és az allergiás fenotípusra:
nemzetközi populációalapú vizsgálat (The effects of growing up on a farm on adult lung function and allergic phenotypes: an international population-based study) Campbell, B., Raherison, C., Lodge, C. J., et al. (Levelező szerző: S. C. Dharmage, Allergy \& Lung

Health Unit, Centre for Epidemiology \& Biostatistics, The University of Melbourne, 207 Bouverie St, Carlton, VIC 3053, Ausztrália): Thorax, 2017, 72(3), 236-244. [Epub 2016 Sep 26]

Az utóbbi évtizedekben az asthmás és az allergiás betegek száma jelentősen megnőtt. A vizsgálatok szerint a korai életkorban kapott környezeti és biodiverzitás expozíció jelentôs az allergia kialakulása szempontjából (higiénéhipotézis). Az erre vonatkozó vizsgálatok nagy része vidéken felnövekedés és gyermekkorban kezdődő megbetegedésekre vonatkozott. Kevés a vizsgálat a korai életkor expozíciója és a felnőttkori megbetegedés közötti összefüggésrôl. Szisztematikus összefoglaló feldolgozások szerint a korai életkori vidéki, farmexpozíció csökkenti a gyermekkori asthma, sípolás és allergiás megbetegedés rizikóját. Jelen vizsgálat célja a korai expozíció hatásának vizsgálata a gyermekkori, serdülőkori, valamint felnőttkori légzésfunkcióra. A European Community Respiratory Health Survey II mintegy 10201 résztvevőt vizsgált 26-54 éves korban 14 országban. A vizsgáltakat aszerint csoportosították, hogy ötéves életkoruk elött farmon, vidéki környezetben vagy belvárosban éltek-e. A biodiverzitás-pontszámot aszerint számolták, hogy a gyermek érintkezett-e macskákkal, kutyákkal, napközi 
otthonos volt-e, hálószoba-megosztás, idősebb testvérek voltak-e. Ezzel összefüggésben elemezték a légzésfunkciót, hörgőhiperreaktivitást, allergiát, asthmát, rhinitist.

$\mathrm{Az}$ összallergia a populációk százalékában, belváros-vidék-farm: 38-31-18\%. A belvárosban felnövekvőkhöz képest a rizikóhányados farmon 0,46 , falu, kisváros, külváros esetén 0,83 . Utóbbi tehát csak mérsékelt csökkenés. Ugyanezen számok asthmára vonatkozóan: $6,1-5,5-4,4 \%$. Rizikóhányados farmon 0,47 , vidéken 0,92 a belvároshoz képest. A rizikóhányados atopiás asthmára 0,43 , illetve 0,90 . Utóbbi nem szignifikáns. Atopiáshörgő-hiperreaktivitásra 0,54 és 0,88 . Ugyanakkor a nem atopiás asthma, nem atopiás rhinitis vonatkozásában nem volt különbség a különböző helyen töltött gyermekkor szerint (rizikóhányadosok 1 körül). Atopiás rhinitisre a rizikóhányados farmon növekedésnél 0,43.
Vidéken növekedésnél 0,90 , tehát nem csökkent a belvároshoz viszonyítva.

A $\mathrm{FEV}_{1} / \mathrm{FVC}$ nem tért el a csoportok között $(80,0-80,6 \%)$. A FEV 1 hasonló sorrendben: férfiakon 4,03-4,06-4,08 1, nôkön 2,97-2,99-3,08 1. Életkor, testsúly, dohányzás, családi allergiás anamnézis szerinti korrekció után a farmon felnőtt nők esetében a $\mathrm{FEV}_{1}$ szignifikánsan, mintegy $110 \mathrm{ml}$-rel nagyobb. Biodiverzitás-pontszám szerint elemezve a belvárosban töltött kisgyermekkor esetén az allergiás rizikó csökkenése összefüggött az emelkedő mikrobiális terhelési pontszámmal. $\mathrm{Ha}$ a biodiverzitás-pontszám 2, akkor a rizikóhányados 0,81 , ha a biodiverzitás-pontszám $4 / 5$, akkor a rizikóhányados 0,70 . De ez még mindig jelentősen elmarad a farm esetén észlelt 0,36 rizikóhányadostól, amely szerint a farmon töltött első öt év az allergiás szenzitizáció veszélyét egyharmadára csökkenti.
$\mathrm{Az}$ észleltek magyarázatát illetően a szerzők irodalmi adatokat említenek, miszerint a környezeti mikrobiális expozíció atopia elleni protektív hatásában a CDI4 gén polimorfizmusa szerepel, továbbá a farmon felnőtt és nem farmon felnőttek között különbség mutatható ki a Toll-like receptor 2 génekben. Feltételezhető az oxidatív stresszel kapcsolatos gének különbsége is.

(Ref.: Az immunrendszer érése a postnatalis időszakban is folytatódik. A genetikai prediszpozició és a különféle környezeti hatások befolyásolják az immuntoleranciában szereplö T-regulációs sejtek alakulását, valamint a kezdeti Th2-túlsúllyal szemben a Th1-válasz-aktivitás fokozódását. A csökkent T-regulációs válasz és a Th2-túlsúly allergiára hajlamosit.)

Nagy László Béla dr.

\section{Ellen Notbohm-Veronica Zysk} EZEREEG NAGYSZERRÜ ÖTLET AUTIZMUSSAL ÉLÓ VAGY ASPERGER-SZINDRÓMÁS GYEREKEK NEVELESESHEZZ ÉSTANITASAAHOZ

„Ha minden iskolában és családban a könyvben szereplő ötletek kis töredékét felhasználnák, beláthatatlan lehetöségek nyilinának meg elöttünk, hogy javítsuk az autizmussal vagy Asperger-szindrómával élö gyermekek életminöségét. Ez pedig csodálatos dolog!"

A könyv számtalan azonnal alkalmazható ötletet kínál szülőknek és nevelőknek az alábbi területeken:

- szenzoros integráció: fejlesztőfeladatok a szabadban és bent,

- kommunikáció: szóhasználat, hallás, vizualitás, környezet,

- viselkedés: tipikus viselkedési formák és kezelésük,

- mindennapi élet: ötletek a mindennapi szituációkhoz, a biztonság megteremtéséhez,

- szociális létezés: barátság, játék, kooperáció, érzelmek.

\section{Dr. Temple Grandin}

